\title{
Modeling epiphytic community production
}

\author{
Gabriella Jackson ${ }^{1,5, *}$, Richard G. Zingmark ${ }^{1,2,3}$, Alan J. Lewitus ${ }^{3,4,6}$ \\ ${ }^{1}$ Marine Science Program, ${ }^{2}$ Department of Biological Sciences and ${ }^{3}$ Belle Baruch Institute, University of South Carolina, \\ Columbia, South Carolina 29208, USA \\ ${ }^{4}$ Hollings Marine Laboratory, Department of Natural Resources, 331 Ft. Johnson Road, Charleston, \\ South Carolina 29412, USA \\ ${ }^{5}$ Present address: Department of Biological Sciences, Central Washington University, Ellensburg, Washington 98926, USA \\ ${ }^{6}$ Present address: NOAA, Center for Sponsored Coastal Ocean Research, Silver Spring, Maryland 20910, USA
}

\begin{abstract}
Mathematical models were used to quantify annual production of the epiphytic community on the saltmarsh cordgrass Spartina alterniflora. Hourly measurements of solar radiation and light attenuation (a function of plant canopy and tidal height) were used as forcing functions in the model. Steeper initial slopes $(\alpha)$ of photosynthesis vs. irradiance curves $(P$ - $I$ curves) were estimated in the summer (when the canopy was densest), indicating highest shade adaptation. Model validation showed a good agreement between actual hourly production measurements and hourly predicted net production $\left(\mathrm{r}^{2}=0.90\right)$. Predicted areal epiphytic community production was negative during all seasons and higher in the high marsh (short $S$. alterniflora zone) than in the low marsh (tall $S$. alterniflora zone), due to a more open canopy and less exposure to tidal waters. The results indicated that the epiphytic community on $S$. alterniflora in North Inlet is an energy sink (i.e. net heterotrophic community). When irradiance values were held constant at $615 \mu \mathrm{mol}$ photons $\mathrm{m}^{-2} \mathrm{~s}^{-1}$ (mean daily irradiance value during daylight), production values were overestimated by 11.68 to $34.77 \%$. Therefore, building quantitative models that include hourly changes in light is key to the realistic estimation of epiphytic production in salt marshes.
\end{abstract}

KEY WORDS: Epiphytic community production $\cdot$ Mathematical modeling $\cdot P$ - $I$ curves $\cdot$ Salt marsh $\cdot$ Spartina alterniflora

- Resale or republication not permitted without written consent of the publisher

\section{INTRODUCTION}

A realistic and useful approach to estimate production is provided by mathematical models. Overall, production models describe photosynthesis with or without photoinhibition. The main parameters shown on photosynthesis vs. irradiance $(P-I)$ curves have been used to develop these models: $\alpha$ (initial slope of the light saturation curve), $P_{\max }$ (maximum photosynthesis), and $\beta$ (present when photoinhibition occurs, it represents the slope of the descending curve at high irradiances). Commonly, the hyperbolic tangent model of Jassby \& Platt (1976) is applied when there is no photoinhibition. However, less complex and widely used models such as Smith's (1936) and Talling's (1957a,b) can also describe $P-I$ curves when photoinhibition is not observed (Lederman \& Tett 1981). The models described by Steele (1962), Vollenweider (1965), Fee (1969), Parker (1974), and Platt et al. (1980) can be used when photoinhibition occurs. However, Coutinho \& Zingmark (1987) suggested that only the parameters described in Platt et al. (1980) had a biological basis.

Traditional production models, such as the ones cited above, are used to extrapolate short-term photosynthetic rate measurements (e.g. hourly) to estimate daily, monthly, and annual production (Pinckney \& Zingmark 1993). However, daily variability in production due to diurnal fluctuations of incident radiation cannot be accurately represented just by simple extrapolation (Peña et al. 1999), which generally re- 
sults in overestimating production rates during periods of low irradiance (early morning or late afternoon). Also, extrapolating daily irradiance from a single hourly measurement does not yield accurate results, because fluctuations in irradiance during the day are not considered (Pinckney \& Zingmark 1991). Therefore, accurate hourly estimates of daily photosynthetically active radiation (PAR) are necessary when modeling daily production, especially for understory intertidal algae. These algae are affected by different light regimes due to tidal cycles (Pinckney \& Zingmark 1991, Peña et al. 1999), attenuation effects of the overlying canopy (Morris 1989), and solar angle (McPherson \& Miller 1987, Pinckney \& Zingmark 1993). According to Peña et al. (1999), the combined effect of plant canopy and overlying water drastically reduce the availability of PAR to algal assemblages during high tide. McPherson \& Miller (1987) demonstrated that solar angle alone caused a $50 \%$ variation in the coefficient of attenuation $(K)$ within a single day in Tampa Bay, Florida, USA. Pinckney \& Zingmark (1993) showed that productivity measurements of benthic microalgae in the North Inlet estuary (South Carolina, USA) could vary largely if solar angles and tidal stages were not considered.

The main goal of the present study was to develop a realistic production simulation model based on the epiphytic community on the cordgrass Spartina alterniflora in the North Inlet estuary (NIE), a pristine salt marsh located near Georgetown, South Carolina, USA. This community, comprised of flagellates, cyanobacteria, diatoms, chlorophytes, amphipods, grass shrimp, and periwinkle snails (Grant 1981, Jackson 2004, Quiñones-Rivera \& Fleeger 2005, Parker et al. 2008), is a potential carbon source to the commercial fishery stocks in many southern states in the USA (Dame et al. 2000).

\section{MATERIALS AND METHODS}

Study area. The NIE $\left(33^{\circ} 20^{\prime} \mathrm{N}, 79^{\circ} 10^{\prime} \mathrm{W}\right)$ is an enclosed small marsh system (ca. 3200 ha) with a welldefined basin and a single inlet (Pinckney 1994). Tides in this estuary are semidiurnal with a mean range of $1.4 \mathrm{~m}$ (Kjerfve et al. 1991).

Spartina alterniflora is the dominant intertidal vegetation and presents well-defined tall and short forms. The tall $S$. alterniflora ( $\geq 1.5 \mathrm{~m}$ height) zone or low marsh extends along the creeks, while short plants ( $\leq 1 \mathrm{~m}$ height) are located in the high marsh, i.e. between the high tide line and the low marsh (Pinckney 1994). Due to seasonal variation in aboveground $S$. alterniflora biomass (Dame \& Kenny 1986, Morris \& Haskin 1990), cordgrass epiphytes are exposed to dif- ferent irradiance levels under the canopy (Morris 1989). Submersion of these plants at high tides also influences the light regime that epiphytes are exposed to due to variations in water depth and the diffuse attenuation coefficient of the overlying water (Vant 1991).

Epiphytic production. Production experiments were conducted monthly from June 2002 to May 2003. Standing tall, dead Spartina alterniflora were randomly sampled at low tide, and their $10 \mathrm{~cm}$ bottom-most section, where the highest epiphytic biomass is generally found (Jackson et al. 2006), was cut and incubated at different light intensities. Epiphytes of S. alterniflora were incubated intact on their own stem in order to minimize disturbance and keep the original integrity and geometry of the community. The definition of $S$. alterniflora stem in the present study consists of imbricate leaves forming the bottom and middle sections of the plant (culm). In the top section, these leaves are found both imbricate and separate from one another.

Glass shell vials (total volume $=47 \mathrm{ml}$ ) were used for incubation, each containing one $5 \mathrm{~cm}$ stem segment from the bottom-most part of dead, tall, standing Spartina alterniflora. Five $\mathrm{cm}$ was the height of the stem that fit into the vials and allowed space to insert an oxygen probe. Stems were placed into $1 \mathrm{~cm}$ stem holders (silicon vacutainer caps taken from $13 \times 75 \mathrm{~mm}$ hematology tubes and glued upside-down to the bottom of each vial with silicon aquarium cement). The $1 \mathrm{~cm}$ section of the stem located inside of the stem holder did not receive light and therefore epiphytes on this section were scraped off in order to preclude their contribution to respiration measurements. Vials containing stems were filled by submerging them in a 41 beaker containing creek water previously filtered through GF/F filters and then capping them while still submerged to avoid contamination by air bubbles. They were then placed upright in a small aquarium $(15 \times 20 \times 30 \mathrm{~cm})$ containing circulating water at constant ambient (creek water) temperature. Incubations were then performed outdoors under full natural light for $30 \mathrm{~min}$. Initial measurements showed that this length of time provided maximum photosynthesis values $\left(P_{\max }\right)$ compared to incubations carried out for 15,45 , and $60 \mathrm{~min}$. All vials were gently rocked every 5 min.

After the first set of samples was incubated under $100 \%$ full sunlight, vials were incubated with progressive layers of neutral density nylon screening to simulate $75,50,25$, and $12.5 \%$ of full sunlight. Six replicates were used for each light intensity. The last set of samples was wrapped in aluminum foil to measure respiration. Multiple measurements were not taken from the same sample because the stirrer of the oxygen meter probe caused epiphytes and sediments to detach from the stems, increasing water turbidity and compromis- 
ing the results of incubations. The absolute photon fluence rate ( $\mu \mathrm{mol}$ photons $\mathrm{m}^{-2} \mathrm{~s}^{-1}$ of PAR, 400 to $700 \mathrm{~nm}$ ) was calculated as the average of values taken at $5 \mathrm{~min}$ intervals during each incubation using a quantum meter (LI-COR model 185B) connected to a spherical quantum sensor (LI-193S).

Dissolved oxygen (DO, $\mathrm{mg} \mathrm{l}^{-1}$ ) and water temperature $\left({ }^{\circ} \mathrm{C}\right)$ in the vials were measured using an oxygen probe (YSI, model 5905), attached to an oxygen meter (YSI, model 59). Oxygen measurements were taken by opening the vials inside a small plastic tent $(30 \times 20 \times$ $20 \mathrm{~cm}$ ), where a continuous flow of nitrogen was used to displace gaseous oxygen inside the tent. This procedure was applied because initial measurements showed that the oxygen inside the tent diffused into the water (due to the oxygen probe stirrer), increasing the final concentrations of DO in the vials. The oxygen meter was selected to estimate net production because it analyzes sequential samples faster and is nondestructive (Pinckney \& Zingmark 1991). Frequent comparisons with Winkler titration differed by $\leq 1 \%$. A major drawback of the oxygen method is a possible overestimation of primary production when $\mathrm{NO}_{3}^{-}$is the nitrogen source, because additional oxygen is released during the reduction of $\mathrm{NO}_{3}^{-}$to $\mathrm{NH}_{4}^{+}$in the algal cells (Raine 1983). The major nitrogen source in NIE for phytoplankton growth is $\mathrm{NH}_{4}^{+}$(Lewitus et al. 1998); therefore, the oxygen method might have not presented a problem for production estimates associated with the epiphytic community.

Final DO measurements were recorded as the difference between the total DO measured at the end of each incubation and initial DO in the creek water at the beginning of incubation. Following all incubations, water in the vials was filtered through a GF/F filter in order to include, in the final biomass analysis, loose epiphytes detached from the stems due to stirring.

Individual stem diameter was measured, and each stem was gently scraped with a rubber policeman 3 times to remove attached epiphytes (Jackson et al. 2006). Epiphytic biomass was measured as chlorophyll a (chl a). All chl $a$ analyses were performed using a Turner Model 450 fluorometer. Details on this pigment extraction were reported in Jackson et al. (2006).

Modeling P-I curves. Several mathematical models (Table 1) were tested to estimate $P-I$ curves, and the selection of the best model to fit the experimental data was based on analyses of the fitting curves and their residuals. If photoinhibition occurred, the models of
Steele (1962), Fee (1969), and Platt et al. (1980) were tested. Other photosynthetic models, such as Vollenweider (1965) and Parker (1974), were not considered as they were designed to calculate photosynthesisdepth curves. If no photoinhibition occurred, Jassby \& Platt (1976) and Smith's (1936) models were tested.

SAS software (version 6.2 for MacIntosh, SAS Institute) was used to perform all $P$ - $I$ curve fitting (through nonlinear least-squares regression) and determine its residuals. Nonlinear regression used the derivativefree Dudley algorithm of Ralston \& Jenrich (1978) to fit $P$ - $I$ curves. Graph Pad Prism (version 4 for MacIntosh, Graph Pad Software) was used to display the graphs. Initial estimates of the main parameters of the equations $\left(P_{\max }, \alpha\right.$, and $\left.\beta\right)$ were based on visual inspection of $P-I$ curves built with raw data points (Gallegos \& Platt 1981), where $P_{\max }$ is the maximum primary production at light saturation, $\alpha$ is the initial linear slope of the curve and represents photosynthetic efficiency, and $\beta$ is the negative slope of the curve generated by photoinhibition. The parameters $a$ and $n$ used in Fee's (1969) equation were the shape parameters of the curve.

Validation of $\boldsymbol{P}$ - $I$ curves. $P$ - $I$ curves used in the present study were validated by randomly splitting the monthly incubation data in half. Each half was treated as an independent set of data and was run separately. The suitability of the equations were evaluated based on: (1) $r^{2}$ values, (2) how closely the data sets followed the raw data plots, (3) how closely the data sets matched each other, and (4) random distribution of the residuals along the $x$-axis.

Production model. The production model developed in the present study was based on the models developed by Pinckney \& Zingmark (1993) for the benthic microalgal community in NIE and by Peña (1998) for mangrove-associated epiphytic macroalgae in Colom-

Table 1. Models used to build seasonal $P$ - $I$ curves of the epiphytic community on Spartina alterniflora in the North Inlet estuary, South Carolina, USA. The equations were recast in terms of $P$ (final primary production), $\alpha$ (initial slope of the light-saturated curve), $P_{\max }$ (maximum photosynthetic rate at $I_{k}$, i.e. minimum light intensity necessary to produce saturated photosynthesis). $I$ is the irradiance at which measurements were made; $P_{\mathrm{s}}$ is similar to $P_{\max }$ and numerically equal when $\beta=0$. The shape parameters of the curves are indicated by $a$ and $n$ in Fee's

(1969) equation. $R$ (respiration) was inserted into the original equations

\begin{tabular}{|ll|}
\hline Equation & Source \\
\hline Photoinhibition & \\
$P=\alpha I \times \exp \left(-\alpha I / P_{\max } \mathrm{e}\right)+R$ & Steele (1962) \\
$\left.P=P_{\max } \times\left(I / I_{\mathrm{k}}\right) /\left\{\left[1+\left(I / I_{\mathrm{k}}\right)^{2}\right] \times\left(1+\left(\alpha I / I_{\mathrm{k}}\right)^{2}\right)\right]^{n}\right\}^{1 / 2}+R$ & Fee (1969) \\
$P=P_{s} \times\left[1-\exp \left(-\alpha I / P_{s}\right)\right]\left[\exp \left(-\beta I / P_{\mathrm{s}}\right)\right]+R$ & Platt et al. (1980) \\
No photoinhibition & \\
$P=P_{\max } \times\left\{(\alpha I) /\left[\left(P_{\max }\right)^{2}+(\alpha I)^{2}\right]^{1 / 2}\right\}+R$ & Smith (1936) \\
$P=P_{\max } \times\left[\tanh \left(\alpha I / P_{\max }\right)\right]+R$ & Jassby \& Platt (1976) \\
\hline
\end{tabular}


bia, South America. The model incorporated 3 parameters considered important in estuarine production of epiphytes on Spartina alterniflora in a tidally driven estuary: irradiance beneath the canopy, in situ irradiance (i.e. irradiance on $S$. alterniflora stems relative to tidal height), and biomass-specific production (based on $P$ - $I$ curves) (Fig. 1).

It was assumed that the light quality was not significantly modified as it passed through the canopy and overlying waters. Various factors that may play an important role in controlling epiphytic production, such as grazing, sloughing/scouring of epiphytes, and self-shading, are difficult to quantify and were not included in the model.

Irradiance beneath the canopy $\left(\boldsymbol{L}_{\mathbf{0}}\right)$. The canopy light attenuation $\left(L_{0}\right)$ model developed by Morris (1989) (Table 2) was used to determine hourly average irradiance beneath the canopy of Spartina alterniflora from June 2002 to May 2003. Morris' (1989) model includes the following parameters: hourly average incident irradiance above the canopy $\left(L_{i}\right)$ (http://links. baruch.sc.edu/Data/) (Fig. 2), solar declination for the hour interval ( $\beta$ ), (HMNAO 2002, 2003) and monthly aboveground $S$. alterniflora weight estimates $(w)$. The canopy weight data for 2002 to 2003 (J. Morris pers. comm.) was restricted to living tall and short $S$. alterniflora plants. Dead S. alterniflora weight for these growth forms was calculated based on the ratio between the weight of dead and living S. alterniflora (Dame \& Kenny 1986). These authors did not measure the biomass of the medium form of $S$. alterniflora; therefore, the production of epiphytes on this plant form was not included in the current final model.

In situ irradiance $\left(\boldsymbol{I}_{\mathrm{s}}\right)$. Irradiance beneath the canopy $\left(L_{0}\right)$, diffuse attenuation coefficient $\left(K_{d}\right)$, and depth of the overlying tidal water $(z)$ were used to calculate in situ irradiance $\left(I_{\mathrm{S}}\right)$ based on the Beer-Lambert Law. The average hourly $K_{d}$ for NIE waters from June 2002 to May 2003 was computed based on linear regressions between turbidity (nephelometer turbidity units, NTU)

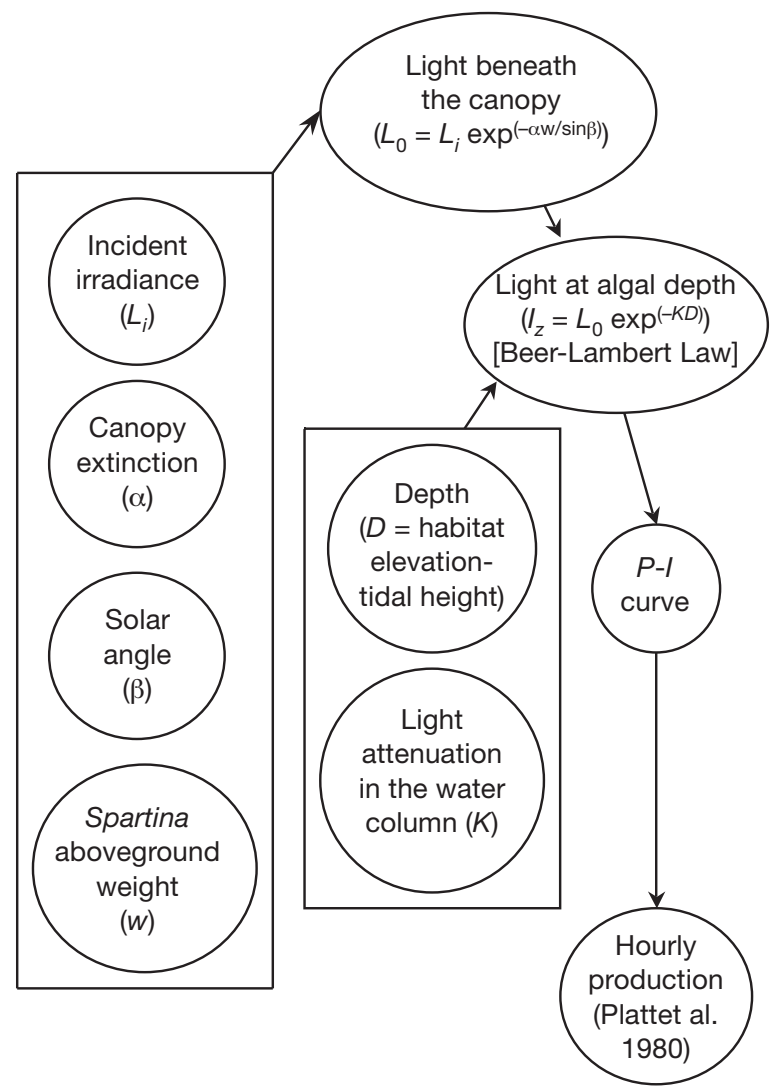

Fig. 1. Conceptual model (adapted and modified from Peña 1998) of the primary factors that affect incident irradiance and production of epiphytes on Spartina alterniflora. I: irradiance; $I_{z}$ : irradiance at depth $Z_{i} P$ : photosynthesis; $L_{0}$ : irradiance beneath canopy

Table 2. Parameters used to build the mathematical production model of epiphytes on Spartina alterniflora in the North Inlet estuary. $D_{\mathrm{s}}$ : Secchi disk depth $(\mathrm{m}) ; L_{i}$ : photosynthetically active radiation (PAR) at the top of the $S$. alterniflora canopy ( $\mu$ mol photons $\left.\mathrm{m}^{-2} \mathrm{~s}^{-1}\right)$; $\beta$ : light extinction coefficient in $S$. alterniflora canopy $\left(0.002 \mathrm{~m}^{-1}\right)$ (Morris 1989); w: $S$. alterniflora canopy dry weight $\left(\mathrm{g} \mathrm{m}^{-2}\right) ; \alpha$ : solar angle above the horizon; $K_{d}$ : PAR diffusion attenuation coefficient $\left(\mathrm{m}^{-1}\right) ; z$ : depth of the overlying tidal water $(\mathrm{m}) ; I$ : irradiance; $P_{\mathrm{s}}$ : maximum photosynthetic rate at $I_{\mathrm{k}} R$ : respiration; $P_{\mathrm{b}}$ : biomass-specific production (calculated using

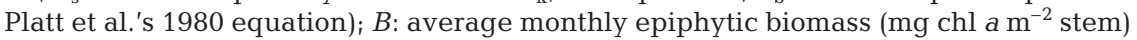

\begin{tabular}{|c|c|c|c|c|}
\hline Parameter & Units & Description & Equation & Source \\
\hline$K_{d}$ & - & Coefficient of attenuation & $1.92 / D_{\mathrm{s}}$ & Coutinho \& Zingmark (1987) \\
\hline$L_{0}$ & $\mu \mathrm{mol}$ photons $\mathrm{m}^{-2} \mathrm{~s}^{-1}$ & $\begin{array}{c}\text { Irradiance beneath } S \text {. alterniflora } \\
\text { canopy }\end{array}$ & $L_{i} \times \exp ^{(-\alpha w / \sin \beta)}$ & Recast from Morris (1989) \\
\hline$I_{\mathrm{s}}$ & $\mu \mathrm{mol}$ photons $\mathrm{m}^{-2} \mathrm{~s}^{-1}$ & In situ irradiance & $L_{0} \times \exp ^{\left(-K_{d} z\right)}$ & Beer-Lambert law \\
\hline$P_{\mathrm{b}}$ & $\operatorname{mg~C~mg~chl~} a^{-1} \mathrm{~h}^{-1}$ & Biomass-specific production & $\begin{array}{l}P_{\mathrm{s}} \times\left[1-\exp \left(-\alpha I / P_{\mathrm{s}}\right)\right] \times \\
\quad\left[\exp \left(-\beta I / P_{\mathrm{s}}\right)\right]+R\end{array}$ & Platt et al. (1980) \\
\hline$P_{\text {as }}$ & $\mathrm{mg} \mathrm{C} \mathrm{m} \mathrm{m}^{-2}$ stem & $\begin{array}{l}\text { Areal epiphytic production } \\
\text { per stem }\end{array}$ & $P_{\mathrm{b}} \times B$ & - \\
\hline$P_{\mathrm{am}}$ & $\mathrm{mg} \mathrm{C} \mathrm{m}{ }^{-2}$ marsh & $\begin{array}{l}\text { Areal epiphytic production } \\
\text { in the marsh }\end{array}$ & $\begin{array}{l}P_{\text {as }} \times \text { no. stems m } \mathrm{m}^{-2} \times \\
\text { surface area stem }\end{array}$ & - \\
\hline
\end{tabular}




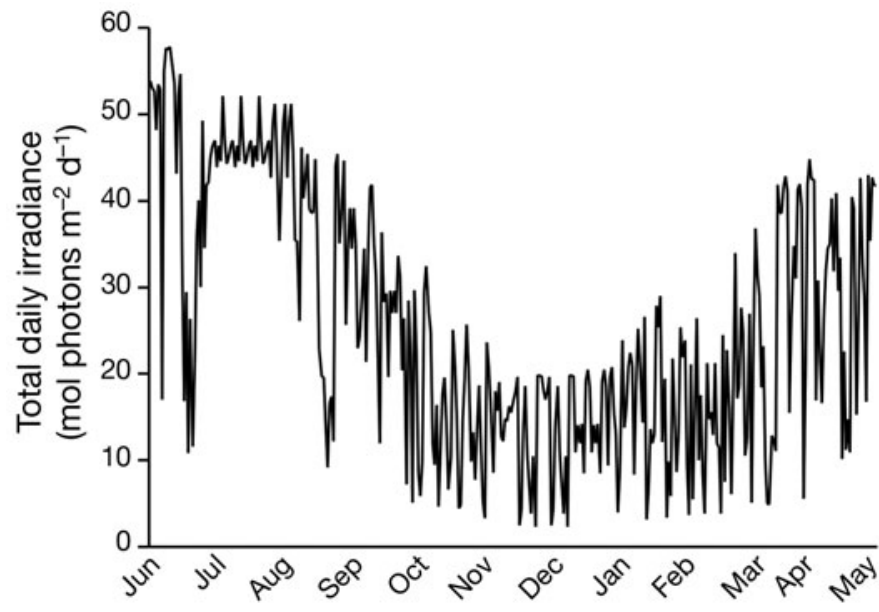

Fig. 2. Daily irradiance from June 2002 through May 2003 at Oyster Landing, North Inlet estuary, South Carolina, USA (http://links.baruch.sc.edu/Data/)

and Secchi disk (cm) measurements taken during 15 consecutive days per month at $2 \mathrm{~h}$ intervals during daytime from June 2002 to May 2003. The coefficient of determination $\left(\mathrm{r}^{2}\right)$ between those parameters was 0.97 , and the equation describing the relationship between them was: Secchi disk $=(-0.0845 \times$ turbidity $)+1.7872$.

The depth of the overlying water was calculated for each hourly interval during the daytime hours as the difference between tidal height measurements and the average habitat elevation (relative to mean low water) of 0.10 and $0.35 \mathrm{~m}$ for tall and short Spartina alterniflora zones, respectively. These values were based on the frequency distribution of $S$. alterniflora plants (Morris et al. 2005). It was assumed that the marsh elevation for tall plants in the NIE ranged from 0 to $0.20 \mathrm{~m}$, and short forms were located at elevations between 0.2 and $0.8 \mathrm{~m}$ above mean low water (J. Morris pers. comm.). Based on data from Morris et al. (2005), the estimated area occupied by tall and short plant forms in the NIE was 1.75 and $16.25 \mathrm{~km}^{2}$, respectively.

Tidal height measurements were not available from the National Estuarine Research Reserve System database for Oyster Landing (OL, a site in the NIE) for the months of August through December 2002 and January 2003. The missing data points were estimated from a regression analysis between tidal height measurements of OL vs. tidal height measurements from the NOAA National Water Level Observation Network in Charleston, South Carolina $\left(\mathrm{r}^{2}=0.87\right)$.

Biomass-specific production $\left(\boldsymbol{P}_{\mathbf{b}}\right)$. Biomass-specific production $\left(P_{\mathrm{b}}\right.$, mg C mg chl $\left.a^{-1} \mathrm{~h}^{-1}\right)$ was obtained experimentally for the bottom section of tall Spartina alterniflora forms from June 2002 to May 2003 and was included in the model. It was assumed that it could also be applied to short forms, as the taxonomic composi- tion of the community on tall and short $S$. alterniflora stems was similar (Jackson 2004).

Model simulation. $P_{\mathrm{b}}$ values were simulated based on hourly $I_{\mathrm{s}}$ (Table 2 ) incorporated into the equations that best fit the $P$ - $I$ curves generated monthly (Table 1$)$. For each day from June 2002 to May 2003, a daily-integrated value of $P_{\mathrm{b}}$ was calculated by summing the values for all the hours from sunrise to sunset, except the hours just after sunrise and just before sunset (i.e. insufficient light for photosynthesis); monthly-integrated values were obtained by summing the values for all days in the month. Monthly values of biomass-specific productivity (mg C mg chl $\mathrm{a}^{-1} \mathrm{mo}^{-1}$ ) were converted to a stem-basis (mg C m${ }^{2}$ stem $^{-1} \mathrm{mo}^{-1}$ ) by multiplying biomass-specific productivity by the mean chl a biomass $\mathrm{m}^{2}$ stem $^{-1}$. Monthly values of epiphytic areal net productivity (mg C $\mathrm{m}^{2}$ marsh $^{-1} \mathrm{mo}^{-1}$ ) were calculated separately for the tall and short forms of Spartina alterniflora. For each form, monthly areal net productivity was calculated as: [stembasis productivity $\times$ surface area $(\text { dead stem })^{-1} \times$ no. dead stems $\mathrm{m}^{-2}$ marsh] + [stem-basis productivity $\times$ surface area (living stem) $)^{-1} \times$ no. living stems $\mathrm{m}^{-2}$ marsh], where the values of surface area (stem) $)^{-1}$ and no. stems $\mathrm{m}^{-2}$ marsh correspond to monthly values and were obtained from Morris (1989), Morris \& Haskin (1990).

Finally, yearly values of epiphytic areal net productivity were obtained by summing over all months in the year.

Model validation. The simulation model was validated through the analyses of the regression coefficient $\left(\mathrm{r}^{2}\right)$ and residual plots from the regression analysis between model-hourly production rates (predicted production) and additional, separate incubations run independently from the ones used to build the model (observed production). A regression coefficient of 0.70 was considered as a minimum value for acceptable reliability of the regression analysis (Cohen et al. 2003). A plot of residuals against the predictor variable was analyzed for linearity of the regression function. If the residuals did not display positive or negative trends, then the appropriateness of the regression model for the data and therefore for the model validation would be supported (Neter et al. 1996).

Sensitivity analyses. Sensitivity analyses (Pinckney \& Zingmark 1993) were used to evaluate the effects of model parameters on annual estimates of epiphytic community production. The effects of cloud cover and daily changes in the amount of sunlight on annual epiphytic production were determined by assuming a constant irradiance of $615 \mu \mathrm{mol}$ photons $\mathrm{m}^{-2} \mathrm{~s}^{-1}$ during the daylight period. The effects of canopy shading and light attenuation during submersion were evaluated by removing each variable and recalculating separately annual production on tall and short Spartina alterniflora forms. 


\section{RESULTS}

The light intensity at the onset of light saturation, $I_{k \prime}$ for the epiphytic community on Spartina alterniflora ranged between 210 and $609 \mu \mathrm{mol}$ photons $\mathrm{m}^{-2} \mathrm{~s}^{-1}$. Analysis of the raw data obtained from the production experiments showed that photoinhibition was evident in all months. Therefore, the models of Steele (1962), Fee (1969), and Platt et al. (1980) were tested to build $P$ - $I$ curves. Visual inspection of the curves, coefficients of determination (ranging between 0.50 and 0.80 ), and residuals showed that the Platt et al. (1980) model was able to best fit the data sets in most of the months (Fig. 3).
The relationship between epiphytic algal biomass and $P_{\max }$ was analyzed to determine if production to be incorporated in the model could be predicted based on epiphytic biomass measurements. Least-squares linear regression showed that the coefficient of determination was ca. 0.60. Regression analysis of observed production vs. hourly-predicted production showed a positive relationship with $\mathrm{r}^{2}=0.90$.

Net monthly areal production on tall Spartina alterniflora ranged from $-0.07 \mathrm{~g} \mathrm{C} \mathrm{m}^{-2}$ (July) to $-83.7 \mathrm{~g} \mathrm{C} \mathrm{m}^{-2}$ (February), while that on short forms varied between -0.08 (July) and $-68 \mathrm{~g} \mathrm{C} \mathrm{m}^{-2}$ (December) (Fig. 4). Monthly values generated by the model showed that epiphytic production tended to follow the day length in
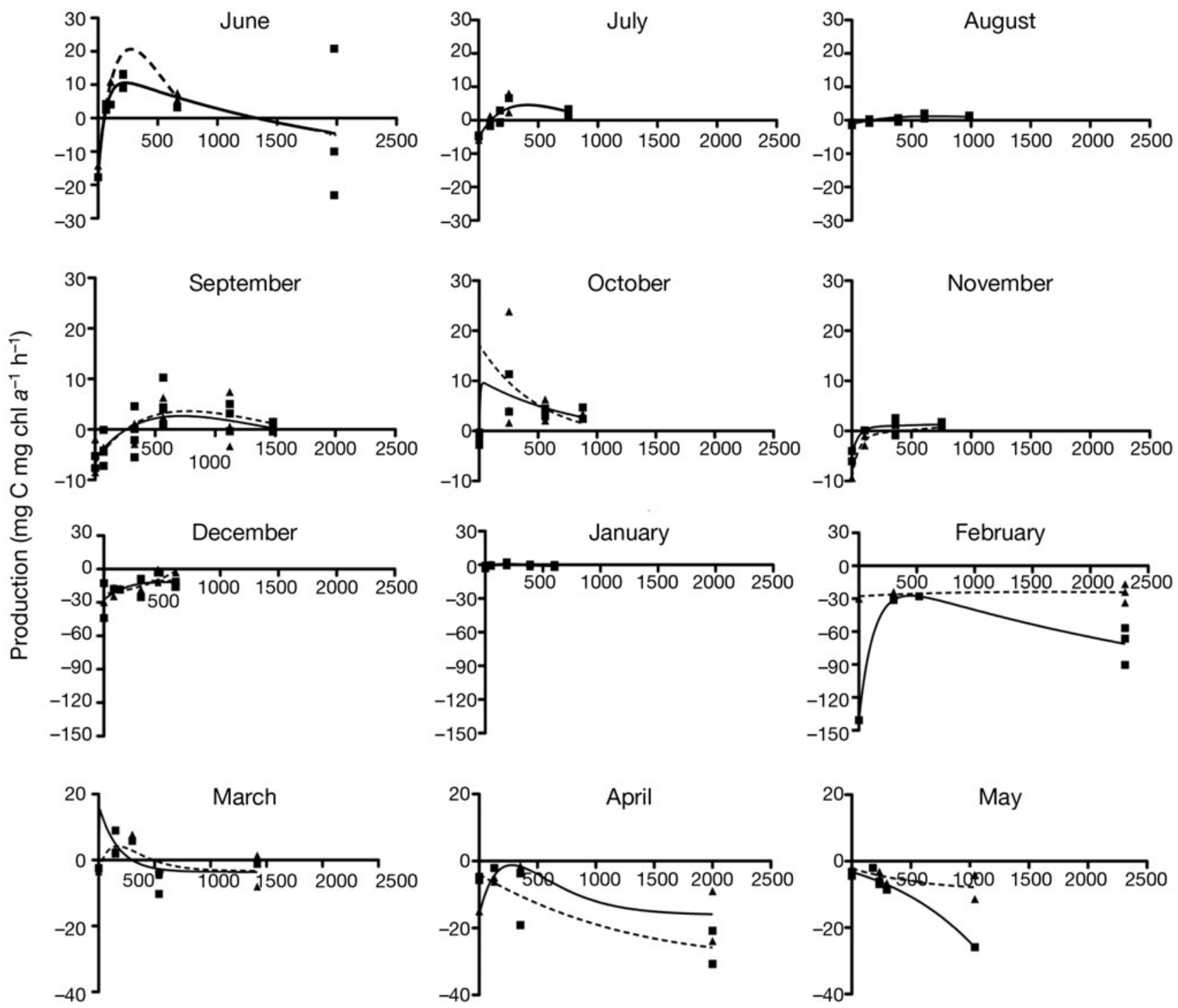

Irradiance ( $\mu \mathrm{mol}$ photons $\mathrm{m}^{-2} \mathrm{~s}^{-1}$ )

Fig. 3. Photosynthesis vs. irradiance curves built using the model developed by Platt et al. (1980). The raw data were split in half and run separately. (ם): raw data for set $1 ;(\mathbf{\Lambda})$ : raw data for set $2 ;(-)$ : curve generated by data set $1 ;(--)$ : curve generated by data set 2 


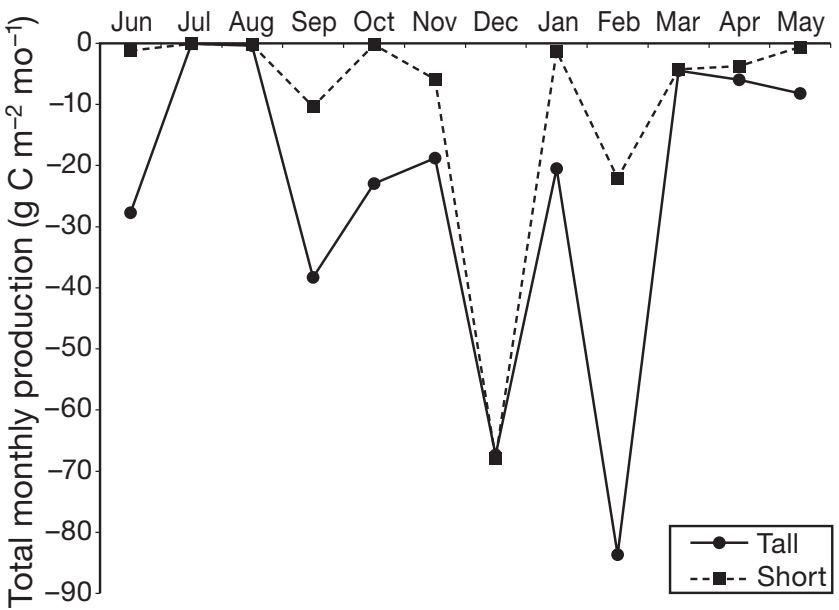

Fig. 4. Model-estimated total monthly production for 2002 and 2003 on tall and short Spartina alterniflora (low and high marsh zones, respectively)

each season, with longer days (summer) (Fig. 2) promoting higher production (Fig. 4). Net production on short $S$. alterniflora tended to be greater than on tall plants (Fig. 4).

Total net annual epiphytic production in the NIE was $-2.94 \times 10^{3} \mathrm{~g} \mathrm{C}$. Although annual production was higher on short Spartina alterniflora (ca. $-143 \mathrm{~g} \mathrm{C} \mathrm{m}^{-2} \mathrm{yr}^{-1}$ ) than on tall forms (-352 $\mathrm{g} \mathrm{C} \mathrm{m}^{-2} \mathrm{yr}^{-1}$; $t$-test, $\left.\mathrm{p}=0.016\right)$, total system production on tall plants $\left(-0.6 \times 10^{3} \mathrm{~g} \mathrm{C} \mathrm{m}^{-2}\right)$ was higher than on short plants $\left(-2.3 \times 10^{3} \mathrm{~g} \mathrm{C} \mathrm{m}^{-2}\right)$ (Table 3$)$.

Table 4 shows estimates of annual epiphytic community production when the irradiance was kept constant, and when the effects of canopy and light attenuation by the water column were removed. As a result, the estimated annual production increased but still remained negative. If the irradiance was kept constant, epiphytes on tall Spartina alterniflora increased production by $6.5 \%$, whereas epiphytes on short plants increased production by $15.1 \%$. Removing the effects of the canopy caused the annual production to increase by 25.1 and $21.4 \%$ on tall and short plants, respectively. When light attenuation was not considered in the model, annual epiphytic community production increases of 41.1 and $12.1 \%$ were estimated on tall and short $S$. alterniflora, respectively.

Table 3. Estimates of total annual production of the Spartina alterniflora epiphytic community in the North Inlet estuary obtained by multiplication of annual net production by the total area occupied by tall and short $S$. alterniflora, respectively. Estimates of area were based on Morris et al. (2005)

\begin{tabular}{|lccc|}
\hline $\begin{array}{l}\text { Spartina growth } \\
\text { forms }\end{array}$ & $\begin{array}{c}\text { Area } \\
\left(\mathrm{km}^{2}\right)\end{array}$ & $\begin{array}{c}\text { Annual net production } \\
\left(\mathrm{g} \mathrm{C} \mathrm{m}^{-2} \mathrm{yr}^{-1}\right)\end{array}$ & $\begin{array}{c}\text { Total system production } \\
\left(\times 10^{6}{\left.\mathrm{~g} \mathrm{C} \mathrm{r}^{-1}\right)}^{-1}\right.\end{array}$ \\
\hline $\begin{array}{l}\text { Tall } \\
\text { Short }\end{array}$ & 1.75 & -351.7 & -615.48 \\
& 16.25 & -142.81 & -2320.66 \\
\hline
\end{tabular}

Table 4. Sensitivity analysis of the model of epiphytic production on tall and short Spartina alterniflora growth forms. Annual values are reported in $\mathrm{g} \mathrm{C} \mathrm{m}^{-2}$

\begin{tabular}{|lcc|}
\hline \multirow{2}{*}{ Function } & \multicolumn{2}{c|}{$\begin{array}{c}\text { Growth form } \\
\end{array}$} \\
& Tall & Short \\
\hline All parameters included & -351.70 & -142.81 \\
$\begin{array}{l}\text { Effects of cloud cover and daily } \\
\text { changes in light removed }\end{array}$ & -328.74 & -121.32 \\
$\begin{array}{l}\text { Effects of light attenuation by } \\
\text { Spartina canopy removed }\end{array}$ & -263.43 & -112.19 \\
$\begin{array}{l}\text { Effects of light attenuation by } \\
\text { water column removed }\end{array}$ & -207.3 & -125.63 \\
\hline
\end{tabular}

\section{DISCUSSION}

\section{P-I curves}

Plots of the raw data in the $P$ - $I$ curves showed that production (mg C mg chl a ${ }^{-1} \mathrm{~h}^{-1}$ ) of the epiphytic community on Spartina alterniflora stems was variable at each light intensity in almost all months. Natural variability of the epiphytic community production from stem to stem (Jackson 2004) might have contributed to this variability. The lowest epiphytic production was registered in the winter. Even though the canopy was more open to light (Morris \& Haskin 1990), lower creek water temperatures during this season likely limited epiphytic production rates.

Photoinhibition occurred in all seasons, suggesting that the epiphytic community was adapted to low irradiance due to Spartina alterniflora canopy. The lowest irradiance values occurred mostly during the summer, when the canopy was densest (Dame \& Kenny 1986, Morris \& Haskin 1990). Steeper initial slopes (higher $\alpha$ values) of $P$-I curves, characteristic of a more photosynthetically efficient, shade-acclimated community, were computed during this season. Alpha $(\alpha)$ is limited by photochemical processes of photosynthesis, and its seasonal pattern is influenced by abiotic factors, such as temperature and light (Platt \& Jassby 1976, Côté \& Platt 1983). Biotic parameters, such as community structure (Côté \& Platt 1983, Binzer \& Middelbore 2005), also influence this parameter, but they did not seem to play an important role in the NIE, as the epiphytic community structure remained similar throughout the seasons (Jackson 2004).

\section{Model validation, simulation, and sensitivity analyses}

The regression analysis of observed hourly production vs. the hourly production obtained by the model exhibited co- 
efficients of determination of 0.90 , which showed that the model could adequately predict changes in epiphytic production on Spartina alterniflora in the NIE. Daily and seasonal light variability are important factors in deriving production models. For example, sensitivity analyses revealed that if changes in irradiance (due to daily variability and light attenuation by the $S$. alterniflora canopy and water column) are not considered, annual production of the epiphytic community might be overestimated by 6.5 to $41.1 \%$, depending on the habitat considered (tall or short Spartina zones). Changes in irradiance (i.e. PAR) and photophysiological responses to shade habitats (i.e. $P$ - $I$ characteristics) played an important role in determining more realistic values of production.

\section{Production estimates and implications for the ecosystem functioning}

All production estimates were negative, indicating net heterotrophic metabolism in the epiphytic community on Spartina alterniflora stems. It is possible that dead stems were loaded with bacteria and, during the incubation, substantial oxygen consumption masked the epiphytic production. However, despite the presence of a heterotrophic community, a relatively high coefficient of determination $\left(r^{2}=0.60\right)$ between biomass of epiphytes and their production suggested that the use of an oxygen meter is a reliable method to measure production of epiphytes on $S$. alterniflora stems. The oxygen method has been commonly used to determine primary production of undisturbed (intact) epiphytic communities (Meulemans 1988), despite the preference of some authors (e.g. Jones 1980, Wear et al. 1999) for the ${ }^{14} \mathrm{C}$ method, which has been considered to provide a more sensitive estimate of the contribution of different taxa to the primary production of the community (Gieskes \& Kraay 1986). The ${ }^{14} \mathrm{C}$ method is relatively expensive and slow when handling multiple samples, and it is not free from experimental artifacts and assumptions that may significantly alter production estimates (Hunding \& Hargrave 1973, Gonzalez et al. 2008). Comparatively, the oxygen method is non-destructive and allows multiple measurements on the same sample over time (Pinckney \& Zingmark 1991).

Monthly and annual epiphytic production differed within Spartina alterniflora zones. Generally, higher marsh elevation and consequently shorter periods of tidal submersion contributed to higher production rates in the high marsh (short $S$. alterniflora zone) compared to the low marsh (tall $S$. alterniflora zone). Lower epiphytic respiration levels in the high marsh may also be the result of a limited the number of heterotrophs due to a lower canopy coverage (lower canopy weight), desiccation stress (high temperature, salinity, and sulfide levels), and a more difficult access from the low marsh to more elevated areas due to dense, tall $S$. alterniflora along the creeks. Higher production in the high marsh also occurs in the microphytobenthos (Pinckney \& Zingmark 1993), and indicates a paradox as the most productive habitat - the short Spartina zone-is the least utilized by herbivores (Pinckney \& Zingmark 1993). However, the presence of just a few predators and abundant food may represent an ideal nursery habitat for herbivores (e.g. meroplanktonic larvae and juveniles) that live in habitats subjected to extreme environmental conditions (Pinckney \& Zingmark 1993).

Epiphytic production also differed between seasons. Seasonal trends in $P_{\max }$ showed a peak in primary production in the summer and fall (October) followed by a second, smaller peak in the spring (May). This trend also was shown for phytoplankton production in the NIE (Sellner et al. 1976), suggesting that seasonal trends in phytoplankton and epiphytic production are similar and therefore these 2 components of the marsh production may be utilized as food resources during the same period of the year.

Water column nutrient limitation may have caused the lowest production observed in the winter, especially in February. During this season, nitrogen and phosphorus concentrations in the NIE are at their lowest (http://links.baruch.sc.edu/data/). It is known that the low concentration of nutrients during the winter is the most important limiting factor to phytoplankton population growth (Lewitus et al. 1998, 2000). Stowe (1982) suggested that nutrients released by the decaying plant host Spartina alterniflora in the winter might be an alternative supply for the epiphytic community. Although $S$. alterniflora senescence is highest during this season in the NIE, nutrients are more available from these plants during the summer, when higher decomposition rates of aboveground $S$. alterniflora occur (Dame \& Kenny 1986).

Salt marshes are among the most productive of the earth's ecosystems (Gallagher et al. 1980, Dame \& Kenny 1986). Measurements of productivity are necessary to quantify specific potential contributions to food webs, as most species of fish and shellfish landed for commercial and sport in the coastal southern states depend on food and energy supplied by specific producers (Hettler 1989). For instance, epiphytes are preyed upon by Littorina irrorata (Currin et al. 1995, R. Zingmark unpubl. data) and Palaemonetes pugio (Quiñones-Rivera \& Fleeger 2005), which in turn are prey for pennaeid shrimps (Kneib \& Knowlton 1995), blue crabs Callinectes sapidus (Silliman \& Bertness 2002), and bay anchovies Anchoa mitchilli (Fulling \& Peterson 1999, Dame et al. 2000). The development of 
the mathematical model presented in the present study, which was based on hourly variability of irradiance due to different parameters, provides more accurate estimates of production and therefore better estimates of food availability (epiphytes) for the ecosystem.

Acknowledgements. This is publication no. 1576 of the Belle W. Baruch Institute for Marine and Coastal Sciences, University of South Carolina. The authors thank R. Tymowski and J. Stuckey for their valuable help during the field work. Dr. J. Spurrier (Department of Statistics, University of South Carolina) and Dr. B. Kjerfve (Department of Oceanography, Texas A \& M) provided helpful comments on the development of the models. We also thank Dr. D. Allen and the North InletWinyah Bay National Estuarine Research Reserve for providing the irradiance and nutrient data. Finally, we thank Dr. J. Cebrian and 3 anonymous referees, whose comments and suggestions improved this manuscript. This study was sponsored by the Ministry of Science and Technology of Brazil/ CAPES through a scholarship (no. 1585/98-3) to G.J. This publication was also supported by EPA grant R826944-01-0 and by the National Sea Grant College Program of the US Department of Commerce's National Oceanic and Atmospheric Administration under NOAA Grant NA060AR4170086.

\section{LITERATURE CITED}

Binzer T, Middelboe AL (2005) From thallus to communities: scale effects and photosynthetic performance in macroalgae communities. Mar Ecol Prog Ser 287:65-75

Cohen J, Cohen P, West SG, Aiken LS (2003) Data visualization, exploration, and assumption checking: diagnosing and solving regression problems. In: Cohen J, Cohen $\mathrm{P}$, West SG, Aiken LS (eds) Applied multiple regression/ correlation analysis for the behavioral sciences, 3rd edn. Lawrence Erlbaum, Hillsdale, NJ, p 101-150

Côté B, Platt T (1983) Day-to-day variations in the springsummer photosynthetic parameters of coastal marine phytoplankton. Limnol Oceanogr 28:320-344

Coutinho R, Zingmark R (1987) Diurnal photosynthetic responses to light by macroalgae. J Phycol 23:336-343

> Currin CA, Newell SY, Paerl HW (1995) The role of standing dead Spartina alterniflora and benthic microalgae in salt marsh food webs: considerations based on multiple stable isotope analysis. Mar Ecol Prog Ser 121:99-116

Dame R, Kenny P (1986) Variability of Spartina alterniflora primary production in the euhaline North Inlet estuary. Mar Ecol Prog Ser 32:71-80

Dame R, Alber M, Allen D, Mallin M and others (2000) Estuaries of the South Atlantic coast of North America: their geographical signatures. Estuaries 23:793-819

Fee EJ (1969) A numerical model for the estimation of photosynthetic production over time and depth in natural waters. Limnol Oceanogr 14:906-911

Fulling GL, Peterson MS (1999) Estimation of small scale patchiness of zooplankton and an associated predator, Anchoa mitchilli. Gulf Res Rep 11:72

Gallagher JL, Reimold RJ, Linthurst RA, and others (1980) Aerial production, mortality, accumulation-export dynamics in Spartina alterniflora and Juncus roemerianus in a Georgia salt marsh. Ecolology 61(2):303-312

Gallegos C, Platt T (1981) Photosynthesis measurements on natural populations of phytoplankton. Can Bull Fish Aquat Sci 210:103-112
Gieskes WWC, Kraay GW (1986) Analysis of phytoplankton pigments by HPLC before, during and after mass occurrence of the microflagellate Corymbellus aureus during the spring bloom in the open northern North Sea in 1983. Mar Biol 92:45-52

González N, Gattuso JP, Middelburg JJ (2008) Oxygen production and carbon fixation in oligotrophic coastal bays and the relationship with gross and net primary production. Aquat Microb Ecol 52:119-130

Grant J (1981) Animal-sediment-water column relations in intertidal sand-burrowing amphipods. $\mathrm{PhD}$ dissertation, University of South Carolina, Columbia, SC

Hettler WF Jr (1989) Nekton use of regularly flooded salt marsh cordgrass habitat in North Carolina, USA. Fish Bull 56:111-118

HMNAO (HM Nautical Almanac Office) (2002) The nautical almanac 2003. Nautical publication no. NP 314-03. The Stationery Office, London

HMNAO (2003) The nautical almanac 2004. Nautical publication no. NP 314-04. The Stationery Office, London

Hunding C, Hargrave BT (1973) A comparison of benthic microalgal production measured by $\mathrm{C}^{14}$ and oxygen methods. J Fish Res Board Can 30:309-312

Jackson MGO (2004) Ecology of the epiphytic microalgal community in North Inlet estuary, SC. PhD dissertation, University of South Carolina, Columbia, SC

Jackson G, Zingmark R, Lewitus AJ, Tymowski R, Stuckey J (2006) Spatial and temporal dynamics of epiphytic microalgae on the cordgrass Spartina alterniflora in North Inlet Estuary, South Carolina. Estuar Coast 29:1212-1221

Jassby AD, Platt T (1976) Mathematical formulation of the relationship between photosynthesis and light for phytoplankton. Limnol Oceanogr 21:540-547

Jones RC (1980) Productivity of algal epiphytes in a Georgia salt marsh: effect of inundation frequency and implications for total marsh productivity. Estuaries 3:315-317

Kjerfve B, Miranda LB, Wolanski E (1991) Modeling water circulation in an estuary and intertidal salt marsh system. Neth J Sea Res 28:141-147

Kneib RT, Knowlton MK (1995) Stage-structure interactions between seasonal and permanent residents of an estuarine nekton community. Oecologia 103:425-434

Lederman TC, Tett P (1981) Problems in modeling the photosynthesis-light relationship for phytoplankton. Bot Mar 24: 125-134

Lewitus AJ, Koepfler ET, Morris JT (1998) Seasonal variation in the regulation of phytoplankton by nitrogen and grazing in a salt-marsh estuary. Limnol Oceanogr 43: 636-646

Lewitus AJ, Koepfler ET, Pigg RJ (2000) Use of dissolved organic nitrogen by a salt marsh phytoplankton bloom community. Adv Limnol 55:15-29

McPherson BF, Miller RL (1987) The vertical attenuation of light in Charlotte Harbor, a shallow, subtropical estuary, south-western Florida. Estuar Coast Shelf Sci 25: $721-737$

Meulemans JT (1988) Seasonal changes in biomass and production of periphyton growing upon reed in Lake Maarsseveen-I. Arch Hydrobiol 112(1):21-42

Morris JT (1989) Modeling light distribution within the canopy of the marsh grass Spartina alterniflora as a function of canopy biomass and solar angle. Agric For Meteorol 46: 349-361

> Morris JT, Haskin B (1990) A 5-yr record of aerial primary production and stand characteristics of Spartina alterniflora. Ecology 71:2209-2217

Morris JT, Porter D, Neet M, Noble PA, Schmidt L, Lapine LA, 
Jensen J (2005) Integrating LIDAR elevation data, multispectral imagery, and neural network modeling for marsh characterization. Int J Remote Sens 26:5221-5234

Neter J, Kutner MH, Nachstsheim CJ, Wasserman W (1996) Applied linear statistical models, 3rd edn. McGraw-Hill, New York

Parker RA (1974) Empirical functions relating metabolic processes in aquatic ecosystems to environmental variables. J Fish Res Board Can 31:1550-1552

Parker JD, Montoya JP, Hay ME (2008) A specialist detritivore links Spartina alterniflora to salt marsh food webs. Mar Ecol Prog Ser 364:87-95

Peña EJS (1998) Physiological ecology of mangrove-associated macroalgae in a tropical estuary. $\mathrm{PhD}$ dissertation, University of South Carolina, Columbia, SC

Peña EJ, Zingmark R, Nietsch C (1999) Comparative photosynthesis of two species of intertidal epiphytic macroalgae on mangrove roots during submersion and emersion. J Phycol 35:1206-1214

Pinckney JL (1994) Development of an irradiance-based ecophysiological model for intertidal benthic microalgal production. In: Krumbein WE, Paterson DM, Stal L (eds) Biostabilization of sediments: microbially mediated processes in tide influenced deposits and their importance in stabilization and diagenesis of sediments. Universität Oldenburg, p 55-83

Pinckney J, Zingmark RG (1991) Effects of tidal stage and sun angles on intertidal benthic microalgal productivity. Mar Ecol Prog Ser 76:81-89

Pinckney JL, Zingmark RG (1993) Modeling the annual production of intertidal benthic microalgae in estuarine ecosystems. J Phycol 29:396-407

Platt T, Jassby AD (1976) The relationship between photosynthesis and light for natural assemblages of coastal marine phytoplankton. J Phycol 12:421-430

Platt T, Gallegos CL, Harrison WG (1980) Photoinhibition of photosynthesis in natural assemblages of marine phytoplankton. J Mar Res 38:687-701

Quiñones-Rivera ZJ, Fleeger JW (2005) The grazing effects of

Editorial responsibility: Matthias Seaman,

Oldendorf/Luhe, Germany grass shrimp, Palaemonetes pugio, on epiphytic microalgae associated with Spartina alterniflora. Estuaries 28: $274-285$

Raine RCT (1983) The effect of nitrogen supply on the photosynthetic quotient of natural phytoplankton assemblages. Bot Mar 26:417-423

Ralston ML, Jenrich RI (1978) Dud, a derivative-free algorithm for non-linear least-squares. Technometrics 20:7-14

Sellner K, Zingmark R, Miller T (1976) Interpretations of the ${ }^{14} \mathrm{C}$ method of measuring the total annual production of phytoplankton in a South Carolina estuary. Bot Mar 19: 119-125

Silliman BR, Bertness MD (2002) A trophic cascade regulates salt marsh primary production. Proc Natl Acad Sci USA 99: 10500-10505

Smith EL (1936) Photosynthesis in relation to light and carbon dioxide. Proc Natl Acad Sci USA 22:504-511

Steele JG (1962) Environmental control of photosynthesis in the sea. Limnol Oceanogr 7:137-150

Stowe WC (1982) Diatoms epiphytic on the emergent grass Spartina alterniflora in a Louisiana salt marsh. Trans Am Microsc Soc 101:162-173

- Talling JF (1957a) Photosynthetic characteristics of some freshwater plankton diatoms in relation to underwater radiation. New Phytol 56:29-50

Talling JF (1957b) The phytoplankton population as a compound photosynthetic system. New Phytol 56:133-149

Vant W (1991) Underwater light in the northern Manukau Harbour, New Zealand. Estuar Coast Shelf Sci 33:291-307

Vollenweider RA (1965) Calculation models of photosynthesis-depth curves and some implications regarding day rate estimates in primary production measurements. In: Goldman CR (ed) Primary productivity in aquatic environments. University of California Press, Berkeley, CA, p 425-457

- Wear DJ, Sullivan MJ, Moore AD, Millie DF (1999) Effects of water-column enrichment on the production dynamics of three seagrass species and their epiphytic algae. Mar Ecol Prog Ser 179:201-213

Submitted: June 19, 2007; Accepted: May 8, 2009

Proofs received from author(s): July 13, 2009 